\title{
Yield and Growth Response to Transplanted Aman Rice under Raised Bed over Conventional Cultivation Method
}

\author{
M. H. M. Bhuyan, ${ }^{1}$ Mst. R. Ferdousi, ${ }^{2}$ and M. T. Iqbal ${ }^{1}$ \\ ${ }^{1}$ Department of Agronomy and Agricultural Extension, University of Rajshahi, Rajshahi 6205, Bangladesh \\ ${ }^{2}$ Islamia Academy High School and Agriculture College, Bagha, Rajshahi 6280, Bangladesh
}

Correspondence should be addressed to M. T. Iqbal, toufiq_iqbal@yahoo.com

Received 6 April 2012; Accepted 26 June 2012

Academic Editors: M. Birkas, T. E. Fenton, and W. P. Williams

Copyright ( $) 2012$ M. H. M. Bhuyan et al. This is an open access article distributed under the Creative Commons Attribution License, which permits unrestricted use, distribution, and reproduction in any medium, provided the original work is properly cited.

Bed planting method for rice production systems is very new and research on it is still at an introductory phase. A field experiment was conducted to determine the effect of different agronomic aspects of bed planting on the growth and yield of transplanted aman rice (both irrigated and rain fed). This study also evaluates the water and fertilizer application efficiency of rice cropping system under bed planting method. Results showed that the bed planting method increased grain yield of rice up to $16 \%$ than the conventional method. Bed planting also increased the number of panicle $\mathrm{m}^{-2}$, number of grains panicle ${ }^{-1}$, and 1000 -grain weight of rice than conventional method. Sterility percentage and weed infestation were lower in bed planting than conventional method. About $42 \%$ of the irrigation water and time for application could be saved through bed planting in transplanted aman rice cropping system. Water use efficiency and crop productivity for grain production were higher in bed planting over conventional method. This study concluded that bed planting method is a new approach for optimum fertilizer and water use efficiency as well as higher yield compared to conventional flat method.

\section{Introduction}

Rice is the major staple food in Bangladesh and the majority of its food grain comes from paddy rice. About $80 \%$ of the cropped area of this country is used for rice production, with annual production of 43.50 million metric tons in total acreage of 11.20 million ha. The average yield of rice in Bangladesh is $3.90 \mathrm{tha}^{-1}$ [1]. This yield of paddy rice in Bangladesh is much lower than existing world average.

Rice production is currently in stagnant condition because farmers do not fully follow the improved techniques in an integrated way, which creates a yield gap. In this situation, farmers, researchers, and scientists are looking for new methods or technologies to get higher rice yield. To meet the increasing food demand, rice production must be increased and continued. Bed planting rice production systems may be a technique for improving the yield. In this system, the land is prepared conventionally and raised bed as well as furrows are prepared manually or using a raised bed planting machine. Crops are planted in rows on top of the raised beds, and irrigation water is applied in the furrows between the beds. Water moves horizontally from the furrows into the beds. This system is often considered for growing high-value crops that are more sensitive to temporary water logging stress. In conventional tillage system for transplanting rice, land is prepared by puddling the soil. For direct seeding of pregerminated rice seed, land is also prepared by puddling. Puddling and continuing inundation until maturity have significant effects on the physical, chemical, and biological status of soils that influence the growing conditions for all crops in the system [2]. Puddling softens soil, facilitates transplanting of rice, promotes root growth, aids weed control, and reduces water and nutrients losses through leaching. Though puddling offers significant advantages to rice it may not be necessary in fine textured soils [3].

Preliminary research on bed planting at the Bangladesh Rice Research Institute [4] showed positive responses. Therefore, bed planting for rice production systems is an emerging researchable issue. Determination of different agronomic aspects of bed planting for rice production systems like 
appropriate width of beds, optimum number of plant rows per bed seed, and fertilizer rates are essential for development of sustainable resource conservation technologies. It will be hypothesized that bed planting method will have more yield, water, and fertilizer use efficiency than conventional method.

\section{Materials and Methods}

2.1. Experimental Site and Soil. The experiment was conducted at the farmer's field in Chuadanga during August to November/2011. The soil of the experiment plot was silt loam with $\mathrm{pH} 7.30$.

2.2. Cultivator. The aman rice variety SORNO was used as an experimental plant. Because, this variety is widely used by the farmers in the Chuadanga district of Bangladesh.

2.3. Experimental Design. The experiment was laid out in a randomized complete block design with three replications. The combination of treatments was randomly distributed in the plots within a block. The unit plot size was $8 \mathrm{~m}^{2}(4 \mathrm{~m} \times$ $2 \mathrm{~m})$.

2.4. Land Preparation. The land was prepared conventionally. The final land preparation was done by ploughing and cross ploughing by two wheel power tiller with two laddering before two days of transplanting. One day before transplanting the plots was laid out as per experimental design.

2.5. Bed Preparation. Raised bed and furrows were made manually by spade following the conventional land preparation. According to the treatments $60 \mathrm{~cm}$ (centre to centre of furrows) width bed were made. For the $60 \mathrm{~cm}$ bed, the top of the raised bed were $35 \mathrm{~cm}$ and furrow between beds were $25 \mathrm{~cm}$. The beds were made one day before transplanting the plots according to lay out of the experiment. The heights of beds were $15 \mathrm{~cm}$.

2.6. Fertilizer Application. The crop was fertilized with N, P, $\mathrm{K}, \mathrm{S}$, and $\mathrm{Zn}$ at the rates of $100,20,35,10$, and $4 \mathrm{~kg} \mathrm{ha}^{-1}$, respectively. The sources of $\mathrm{N}, \mathrm{P}, \mathrm{K}, \mathrm{S}$, and $\mathrm{Zn}$ were urea, TSP, MP, gypsum, and $\mathrm{ZnSO}_{4}$, respectively. The all of TSP, $\mathrm{MP}$, gypsum, and $\mathrm{ZnSO}_{4}$ were applied at the time of final land preparation as basal dose in the plots with conventional treatment. In the plots with bed planting treatments, the basal doses were applied before transplanting on the top of the beds. The urea was top dressed in three equal splits at 15, 30, and 50 days after transplanting (DAT).

2.7. Transplanting of Seedlings. Thirty day old seedlings were uprooted from the seedbed without making any injury to them and transplanted on the same day. Two to three seedlings hill ${ }^{-1}$ were transplanted maintaining row spacing at $25 \mathrm{~cm}$ and plant to plant spacing of $15 \mathrm{~cm}$. Irrigation water was applied one day before transplanting between the furrows of bed to make the soil soft.
2.8. Irrigation. Though transplant aman rice was a rain fed crop, supplemental irrigation was needed for preparation of the plots with conventional treatment and for the bed planting of all plots. Another supplemental irrigation was done for all plots at flowering stage of rice.

2.9. Weeding. Manual weeding was done twice in the transplant aman rice field during growth period. The plots were weeded at 15 and 30 DAT. Weed samples from each plot were collected at the time of weeding for comparing weed population and dry biomass yield of different treatments.

2.10. Pest Control. The rice was infested by stem borer at tillering stage and by rice bug at grain filling stage. Furadan $5 \mathrm{G}$ at the rate of $10 \mathrm{~kg} \mathrm{ha}^{-1}$ was applied at $40 \mathrm{DAS}$ and Malathion $57 \mathrm{EC} 5 \mathrm{G}$ at the rate of $1 \mathrm{~L} \mathrm{ha}^{-1}$ was applied at grain filling stage to control stem borer and rice bug, respectively.

2.11. Crop Harvesting. Rice was harvested and threshed by using pedal thresher.

2.12. Statistical Analysis of Data. The experiment was conducted with randomized complete block design replicated three times. All statistical analysis was conducted by $t$ test.

\section{Results}

3.1. Grain Yield and Yield Components. The yield increase by bed planting over conventional method was 16\%. A similar finding was also found in panicles; grains per panicle and 1000 gm grain wt. Raised bed planting had more 50 panicle number $\mathrm{m}^{-2}, 21$ grain number per panicle and $0.19 \mathrm{gm}$ in 1000 grain wt than conventional method. Likewise, grain yield and yield components significantly $(P \leq 0.01)$ differed between bed planting and the conventional method (Table 1).

3.2. Other Plant Attributes. Planting method affected plant height, panicle length, nonbearing tillers $\mathrm{m}^{-2}$, sterility percentage, straw yield, and harvest index of transplanted aman rice. Plant height, panicle length, and harvest index were higher in bed planting than conventional method. On the contrary, nonbearing tillers $\mathrm{m}^{-2}$ and sterility percentage were higher in conventional method than bed planting. Likewise, lower number of nonbearing tillers $\mathrm{m}^{-2}$ was recorded in bed planting treatments than conventional method. Bed planting significantly $(P \leq 0.01)$ reduced the sterility percentage as compared to conventional method. In bed planting sterility was lower as compared to conventional method. The lower sterility might be accountable for higher grains in bed planting. Bed planting resulted in higher harvest index than conventional method (Table 2).

3.3. Tiller Production. Transplanting of aman rice under different planting method affected the number of tillers $\mathrm{m}^{-2}$ of rice. The increasing trend of tillers $\mathrm{m}^{-2}$ was continued 
TABLE 1: Grain yield and yield components with respect to fertilizer application.

\begin{tabular}{lcccc}
\hline \multirow{2}{*}{ Method of fertilizer application } & \multicolumn{3}{c}{ Yield and yield components } \\
& Grain yield $\left(\mathrm{t} \mathrm{ha}^{-1}\right)$ & Panicles m $^{-2}(\mathrm{no})$ & Grains panicle $^{-1}(\mathrm{no})$ & $1000 \mathrm{grain} \mathrm{wt}(\mathrm{gm})^{23.01 \mathrm{a}}$ \\
\hline Fertilizer broadcasting in raised bed & $5.83 \mathrm{a}$ & $417 \mathrm{a}$ & $161 \mathrm{a}$ & $140 \mathrm{~b}$ \\
Fertilizer broadcasting in conventional plot & $4.90 \mathrm{~b}$ & $367 \mathrm{~b}$ & 4.59 & $22.82 \mathrm{~b}$ \\
Coefficient of variation CV (\%) & 5.31 & 4.10 & $* 30$ & $* *$ \\
Level of significance & $* *$ & $* *$ & $* *$ \\
\hline
\end{tabular}

Where ${ }^{* *}$ represent probability of $\leq 0.01$. Values were means of three replicates. In a column figures with same letter do not differ significantly whereas figures with dissimilar letter differ significantly $(P \leq 0.01)$.

TABLe 2: Plant biomass with respect to raised bed and conventional method.

\begin{tabular}{|c|c|c|c|c|c|c|}
\hline Method of fertilizer application & $\begin{array}{l}\text { Plant height } \\
(\mathrm{cm})\end{array}$ & $\begin{array}{l}\text { Panicle } \\
\text { Length } \\
(\mathrm{cm})\end{array}$ & $\begin{array}{c}\text { Nonbearing } \\
\text { tiller } \\
\left(\text { no. }^{-2}\right)\end{array}$ & Sterility (\%) & $\begin{array}{l}\text { Straw yield } \\
\left(\text { tha }^{-1}\right)\end{array}$ & Harvest index \\
\hline Fertilizer broadcasting in raised bed & $87.23 \mathrm{a}$ & $24.88 \mathrm{a}$ & $67 b$ & $10.16 b$ & $5.60 \mathrm{a}$ & $0.51 \mathrm{a}$ \\
\hline Fertilizer broadcasting in conventional plot & $86.38 b$ & $24.30 \mathrm{~b}$ & $78 \mathrm{a}$ & $12.41 \mathrm{a}$ & $4.92 b$ & $0.49 b$ \\
\hline Coefficient of variation CV (\%) & 3.25 & 3.47 & 4.25 & 6.14 & 4.52 & 5.30 \\
\hline Level of significance & $* *$ & $* *$ & $* *$ & $* *$ & $* *$ & $* *$ \\
\hline
\end{tabular}

Where ${ }^{* *}$ represents probability of $\leq 0.01$. Values were means of three replicates. In a column figures with same letter do not differ significantly, whereas figures with dissimilar letter differ significantly $(P \leq 0.01)$.

TABLE 3: Effect of tiller production in both raised bed and conventional method.

\begin{tabular}{lccccccccc}
\hline & & \multicolumn{9}{c}{ Tiller $\left(\right.$ no.m $\left.^{-2}\right)$ at days after transplanting } \\
Method of fertilizer application & 20 & 30 & 40 & 50 & 60 & 70 & 80 & 90 & 100 \\
\hline Fertilizer broadcasting in raised bed & $235 \mathrm{a}$ & $543 \mathrm{a}$ & $588 \mathrm{a}$ & $626 \mathrm{a}$ & $514 \mathrm{a}$ & $502 \mathrm{a}$ & $595 \mathrm{a}$ & $489 \mathrm{a}$ & $484 \mathrm{a}$ \\
Fertilizer broadcasting in conventional plot & $196 \mathrm{a}$ & $367 \mathrm{a}$ & $441 \mathrm{a}$ & $522 \mathrm{~b}$ & $490 \mathrm{~b}$ & $470 \mathrm{~b}$ & $462 \mathrm{~b}$ & $450 \mathrm{~b}$ & $445 \mathrm{~b}$ \\
Coefficient of variation CV (\%) & 6.58 & 6.95 & 7.10 & 4.55 & 5.37 & 6.45 & 7.25 & 6.48 & 5.17 \\
Level of significance & n.s. & n.s. & n.s. & $* *$ & $*$ & $* *$ & $* *$ & $* *$ & $* *$ \\
\hline
\end{tabular}

Where n.s. ${ }^{*}$ and ${ }^{* *}$ represent probability of $>0.05, \leq 0.05$, and $\leq 0.01$, respectively. Values were means of three replicates. In a column figures with same letter do not differ significantly, whereas figures with dissimilar letter differ significantly $(P \leq 0.01)$.

to 50 DAT. At 50 DAT both planting methods attained the highest number of tiller $\mathrm{m}^{-2}$ and then started declining up to 100 DAT. Interestingly, tiller number did not differ significantly up to 40 days after transplanting in both raised bed and transplanting method. However, both methods differ significantly $(P \leq 0.01)$ from 60 to 100 days after transplanting (Table 3).

3.4. Leaf Area Index. Planting method affected the leaf area index of transplant aman rice recorded at different DAT. Plant-to-plant distance in rows also influenced the leaf area index measured at different stages of crop growth. The highest leaf area index (LAI) was achieved at flowering stage (80 DAT) by planting method. It was also revealed that at early stage of crop growth the leaf area index of bed planting treatments was lower than conventional method and at maximum tillering stage to next stages. Result showed that LAI did not differ significantly between two methods at 20 days after transplanting. However, LAI differs significantly $(P$ $\leq 0.01$ ) between two methods from 40 to 100 DAT (Table 4 ).

3.5. Dry Matter Production. Planting method affected the dry matter production of transplanted aman rice recorded at different days after transplanting (DAT). In the first date of measurement (20 DAT) it was observed that the conventional method produced higher dry matter yield than bed planting. Likewise, at the final date (100 DAT) highest dry matter production was also recorded in conventional method than bed planting method. However, dry matter production differs significantly $(P \leq 0.01)$ at different days after transplanting except 60 and 70 DAT in both methods (Table 5).

3.6. Crop Growth Rate. At the initial stage (20 to $40 \mathrm{DAT}$ ), the crop growth rate in bed planting was lower than conventional method. The greatest crop growth was observed at 50 
TABLE 4: Effect of leaf area index in both raised bed and conventional method.

\begin{tabular}{|c|c|c|c|c|c|}
\hline \multirow{2}{*}{ Method of fertilizer application } & \multicolumn{5}{|c|}{ LAI at different DAT } \\
\hline & 20 & 40 & 60 & 80 & 100 \\
\hline Fertilizer broadcasting in raised bed & $0.60 \mathrm{a}$ & $4.96 b$ & $6.57 b$ & $8.35 b$ & $6.26 \mathrm{~b}$ \\
\hline Fertilizer broadcasting in conventional plot & $1.32 \mathrm{a}$ & $6.23 \mathrm{a}$ & $12.47 \mathrm{a}$ & $12.62 \mathrm{a}$ & $9.47 \mathrm{a}$ \\
\hline Coefficient of variation CV (\%) & 4.52 & 6.28 & 7.45 & 8.25 & 5.17 \\
\hline Level of significance & n.s. & $* *$ & $* *$ & n.s. & $*$ \\
\hline
\end{tabular}

Where n.s. ${ }^{*}$ and ${ }^{* *}$ represent probability of $>0.05, \leq 0.05$, and $\leq 0.01$, respectively. Values were means of three replicates. In a column figures with same letter do not differ significantly whereas figures with dissimilar letter differ significantly $(P \leq 0.01)$.

TABLE 5: Effect of dry matter production in both raised bed and conventional method.

\begin{tabular}{lccccccccc}
\hline \multirow{2}{*}{ Method of fertilizer application } & \multicolumn{3}{c}{ Dry matter production $\left(\mathrm{g} \mathrm{m}^{-2}\right)$ at different days after transplanting (DAT) } \\
& 20 & 30 & 40 & 50 & 60 & 70 & 80 & 90 & 100 \\
\hline Fertilizer broadcasting in raised bed & $75 \mathrm{~b}$ & $218 \mathrm{~b}$ & $617 \mathrm{~b}$ & $734 \mathrm{~b}$ & $1162 \mathrm{a}$ & $1450 \mathrm{a}$ & $1765 \mathrm{~b}$ & $2083 \mathrm{~b}$ & $2250 \mathrm{~b}$ \\
Fertilizer broadcasting in conventional plot & $107 \mathrm{a}$ & $317 \mathrm{a}$ & $835 \mathrm{a}$ & $1160 \mathrm{a}$ & $2282 \mathrm{a}$ & $2825 \mathrm{a}$ & $3970 \mathrm{a}$ & $4724 \mathrm{a}$ & $5101 \mathrm{a}$ \\
Coefficient of variation CV (\%) & 6.45 & 7.45 & 6.33 & 8.45 & 7.10 & 4.58 & 5.29 & 7.11 & 4.56 \\
Level of significance & $* *$ & $* *$ & $* *$ & $* *$ & n.s. & n.s. & $*$ & $* *$ & $* *$ \\
\hline
\end{tabular}

Where n.s. ${ }^{*}$ and ${ }^{* *}$ represent probability of $>0.05, \leq 0.05$, and $\leq 0.01$, respectively. Values were means of three replicates. In a column figures with same letter do not differ significantly, whereas figures with dissimilar letter differ significantly $(P \leq 0.01)$.

TABLE 6: Effect of crop growth rate in both raised bed and conventional method.

\begin{tabular}{|c|c|c|c|c|c|c|c|c|}
\hline \multirow{2}{*}{ Method of fertilizer application } & \multicolumn{8}{|c|}{ Crop growth rate $\left(\mathrm{g} \mathrm{m}^{-2}\right.$ day $\left.^{-1}\right)$ at different days after transplanting (DAT) } \\
\hline & $20-30$ & $30-40$ & $40-50$ & $50-60$ & $60-70$ & $70-80$ & $80-90$ & $90-100$ \\
\hline Fertilizer broadcasting in raised bed & $14.3 \mathrm{~b}$ & $39.9 \mathrm{~b}$ & $11.8 \mathrm{~b}$ & $42.8 \mathrm{~b}$ & $28.8 \mathrm{~b}$ & $31.5 b$ & $31.80 \mathrm{~b}$ & $16.70 \mathrm{~b}$ \\
\hline Fertilizer broadcasting in conventional plot & $21 \mathrm{a}$ & $51.8 \mathrm{a}$ & $2.5 \mathrm{a}$ & $111.2 \mathrm{a}$ & $54.3 \mathrm{a}$ & $4.5 \mathrm{a}$ & $75.4 \mathrm{a}$ & $37.7 \mathrm{a}$ \\
\hline Coefficient of variation CV (\%) & 5.26 & 5.78 & 6.10 & 4.88 & 6.49 & 6.70 & 8.20 & 4.91 \\
\hline Level of significance & $* *$ & $* *$ & $* *$ & $* *$ & $* *$ & $* *$ & $* *$ & $* *$ \\
\hline
\end{tabular}

Where $* *$ represents probability of $\leq 0.01$. Values were means of three replicates. In a column figures with same letter do not differ significantly, whereas figures with dissimilar letter differ significantly $(P \leq 0.01)$.

to 60 DAT in both planting method. However, crop growth rate significantly $(P \leq 0.01)$ differed between both methods at all DAT (Table 6).

3.7. Weed Population. Weed population and dry biomass were greatly influenced by different planting methods of transplanted aman rice. The bed planting method reduced weed population resulting in lower dry biomass than the conventional method. The conventional method had significantly $(P \leq 0.01)$ higher weed vegetation than the raised bed method (Table 7).

3.8. Irrigation Water. Amount of water required for different irrigations differed remarkably between the conventional and bed planting methods. The conventional method received the higher amount of water at every irrigation and total amount was $142.66 \mathrm{~cm}$. In bed planting method total amount received was $100.47 \mathrm{~cm}$. Result showed that total water savings by bed over conventional method were $42 \%$. At transplanting and reproductive stage, conventional method required significantly $(P \leq 0.01)$ higher irrigation water than raised bed method (Table 8 ).
3.9. Water Use Efficiency. Water use efficiency for grain production and biomass production in bed planting was $51 \mathrm{~kg} \mathrm{ha}^{-1} \mathrm{~cm}^{-1}$ and $114 \mathrm{~kg} \mathrm{ha}^{-1} \mathrm{~cm}^{-1}$, respectively. In contrast, water use efficiency for grain production and biomass production in conventional planting was 29 and $69 \mathrm{~kg} \mathrm{ha}^{-1} \mathrm{~cm}^{-1}$, respectively. However, water used efficiency for grain production and biomass production by bed planting over conventional was $57 \%$ and $61 \%$, respectively (Table 9). In addition, water use efficiency for grain production is calculated by grain yield $\left(\mathrm{kg} \mathrm{ha}^{-1}\right)$ to irrigation required $(\mathrm{cm})$. Likewise, water use efficiency for biomass production is calculated by grain yield $\left(\mathrm{kg} \mathrm{ha}^{-1}\right)$ plus straw yield $\left(\mathrm{kg} \mathrm{ha}^{-1}\right)$ to irrigation required $(\mathrm{cm})$.

3.10. Agronomic Efficiency of Nitrogen Fertilizer. Agronomic efficiency (AE) of nitrogen fertilizer in raised bed was $32.15 \%$. On the other hand AE for conventional plot was $27 \%$. So, AE in raised bed was $20 \%$ higher than conventional plot (Table 10). In addition, AE of nitrogen fertilizer was calculated by the following equation:

$$
\mathrm{AE}=\frac{\left(\mathrm{GYN}_{\mathrm{a}}-\mathrm{GYL}_{0}\right)}{\mathrm{NR}}
$$


TABLE 7: Effect of weed growth in both raised bed and conventional method.

\begin{tabular}{|c|c|c|}
\hline \multirow{2}{*}{ Method of fertilizer application } & \multicolumn{2}{|c|}{ Weed vegetation } \\
\hline & Weed vegetation population $\left(\right.$ no. $^{-2}$ ) & Dry biomass $\left(\mathrm{kg} \mathrm{ha}^{-1}\right)$ \\
\hline Fertilizer broadcasting in raised bed & $123 \mathrm{~b}$ & $113.3 \mathrm{~b}$ \\
\hline Fertilizer broadcasting in conventional plot & $380 \mathrm{a}$ & $337 \mathrm{a}$ \\
\hline Coefficient of variation CV (\%) & 8.14 & 6.47 \\
\hline Level of significance & $* *$ & $* *$ \\
\hline
\end{tabular}

Where ${ }^{* *}$ represents probability of $\leq 0.01$. In a column figures with same letter do not differ significantly, whereas figures with dissimilar letter differ significantly $(P \leq 0.01)$.

TABLE 8: Irrigation water savings by bed planting of rice production over conventional method.

\begin{tabular}{|c|c|c|c|c|c|c|}
\hline \multirow[b]{2}{*}{ Method of fertilizer application } & \multicolumn{5}{|c|}{ Water required at different times of irrigation $(\mathrm{cm})$} & \multirow{2}{*}{$\begin{array}{l}\text { Water saved over } \\
\text { conventional method } \\
(\%)\end{array}$} \\
\hline & $\begin{array}{c}\text { Land } \\
\text { preparation }\end{array}$ & Transplanting & $\begin{array}{l}\text { Reproductive } \\
\text { stage }\end{array}$ & Rainfall & Total & \\
\hline Fertilizer broadcasting in raised bed & - & $6.35 \mathrm{a}$ & $41.62 b$ & $52.50 \mathrm{a}$ & $100.47 b$ & \\
\hline Fertilizer broadcasting in conventional plot & 13.06 & $6.20 \mathrm{~b}$ & $70.90 \mathrm{a}$ & $52.50 \mathrm{a}$ & $142.66 \mathrm{a}$ & \\
\hline Coefficient of variation CV (\%) & - & 3.54 & 7.25 & 6.33 & 4.37 & $42 \%$ \\
\hline Level of significance & - & $* *$ & $* *$ & n.s. & $* *$ & \\
\hline
\end{tabular}

Where n.s. and ${ }^{* *}$ represent probability of $>0.05$ and $\leq 0.01$, respectively. In a column figures with same letter do not differ significantly, whereas figures with dissimilar letter differ significantly $(P \leq 0.01)$.

TABLE 9: Water use efficiency in both raised bed and conventional method.

\begin{tabular}{lcc}
\hline Method of fertilizer application & $\begin{array}{c}\text { Water use efficiency savings by bed planting of rice over conventional method } \\
\text { Water use efficiency for biomass } \\
\text { production } \\
\left(\mathrm{kg} \mathrm{ha}^{-1} \mathrm{~cm}^{-1}\right)\end{array}$ & $\begin{array}{c}\text { Water use efficiency for grain production } \\
\left(\mathrm{kg} \mathrm{ha}^{-1} \mathrm{~cm}^{-1}\right)\end{array}$ \\
\hline Fertilizer broadcasting in raised bed & $51 \mathrm{a}$ & $29 \mathrm{~b}$ \\
Fertilizer broadcasting in conventional plot & 5.12 & $69 \mathrm{~b}$ \\
Coefficient of variation CV $(\%)$ & $* *$ & 3.99 \\
Level of significance & $\begin{array}{c}\text { (1) } \\
\text { Where } * \text { and } * * \text { represent probability of } \leq 0.05 \text { and } \leq 0.01 \text {, respectively. Values were means of three replicates. In a column figures with same letter do not }\end{array}$
\end{tabular}

TABle 10: Agronomic efficiency of fertilizer in both bed and conventional plot.

Method of Fertilizer application

Agronomic efficiency of fertilizer (\%)

Fertilizer application broadcasting in raised bed

32.15

Fertilizer application broadcasting in conventional plot

27

where, GYNa is grain yield $\left(\mathrm{kg} \mathrm{ha}^{-1}\right)$ with addition of nutrient, $\mathrm{GYL}_{0}$ is grain yield $\left(\mathrm{kgha}^{-1}\right)$ without addition of nutrient, NR is rate of added nutrient.

\section{Discussion}

4.1. Bed Planting Method Produces Higher Biomass and Yield than Conventional Method. The number of panicles $\mathrm{m}^{-2}$ was significantly $(P \leq 0.01)$ higher in bed planting over conventional method. The difference of panicles number was $50 \mathrm{~m}^{-2}$ between these methods (Table 1). Bed planting method produced significantly $(P \leq 0.01)$ higher grains panicle than conventional method. Likewise, Borrell et al. [5] found that panicles number $\mathrm{m}^{-2}$ in rice plant for raised bed planting and flooded method was 228 and 210, respectively. They also found that panicle number per plant in raised bed and flooded methods was 2.3 and 2.0, respectively. They speculated that raised bed method has the potential to better utilize water and nutrients than conventional methods. This may result higher panicle number per plant in raised bed than conventional method.

Tiller production in raised bed was significantly $(P \leq$ $0.01)$ greater in bed planting over conventional method (Table 3). Singh et al. [6] found that number of tillers of rice plant is almost double in bed planting over conventional method. They suggested that rice plant was generally sustained on the beds relative to conventional methods could be due to more rapid drying of the beds than flats, due to 
greater surface area and the greater concentration of roots in the bed tops.

Weight of 1000 grain was also significantly higher in bed planting than conventional method (Table 1). Yadav et al. [7], Zhongming and Fahong [8], and Meisner et at. [9] reported similar results. Likewise, Choudhury et al. [10] found that 1000 grain per $\mathrm{g}$ in flat bed and raised bed was 20.0 and 20.5, respectively. They speculated that higher grain production in raised bed than flat method could be due to management and geometry of bed, less weed population, and better crop establishment.

Raised bed planting method had $0.93 \mathrm{tha}^{-1}$ higher rice production than conventional method (Table 1 ). The yield increased by bed planting in transplant aman rice compared to conventional method was also reported by Hobbs and Gupta [11], Balasubramanian et al. [12], Meisner et al. [9], and Jat and Sharma [13]. Likewise, Tang et al. [14] also reported that bed planting method significantly increased rice yield by $6.7 \%$ compared with traditional cropping technique. Moreover, Ockerby and Fukai [15] confirmed that yield of rice grown on raised beds was greater than rice grown in conventional method. They advised that effective $\mathrm{N}$ fertilizer utilized by rice paddy plants influenced better rice production in raised bed system. Other study speculated that potential agronomic advances of beds include improved soil structure due to reduced compaction through controlled trafficking and reduced water logging condition is responsible for improved rice production [16]. Likewise, Govaerts et al. [17] also suggested that bed planting provides a natural opportunity to reduce compaction by confining traffic to the furrow bottoms that increased rice production.

4.2. Bed Planting Method Has Less Weed Growth than Conventional Method. Weed production was significantly $(P$ $\leq 0.01$ ) lower in bed planting than conventional method. Likewise, existing weed vegetation was significantly $(P \leq$ $0.01)$ lower in raised bed planting than conventional method (Table 7). Singh et al. [18] found that total weed dry weight and weed density were lower in raised bed planting method as compared to conventionally puddled transplanted rice. Similarly, Ram et al. [19] also found lower weed biomass in raised beds than the conventional method. They speculated that the low number of weeds in beds might be due to dry top surface of beds that inhibited the weed growth. However, our speculation is that, at the time of bed preparation, the top soils of the furrows were mulched to the raised beds, which drastically reduced the weeds in furrow. Another probable cause was that the soil was not disturbed in the zero tillage systems under bed planting method. Moreover, other speculation is that this difference of weed growth between bed planting and conventional method may be due to agronomic management practices. In bed planting method, rice plants were grown in wet conditions while in conventional methods, rice plants were grown under standing water condition. This difference in weed growth between these two methods could also have been due to the contrasting weed flora and soil moisture conditions of fields. Likewise, Hobbs [20] opined that bed planting method reduces weed growth compared with conventional flat-bed planting method. He also suggested that bed planting provides additional options to farmers for controlling weeds. Similarly, Jat et al. [21] suggested that planting of crops on raised bed systems reduces weed competition over conventional method. By adopting raised bed system, fertilizers are banded close to the rows enhancing crop accessibility to nutrient and competitiveness over weeds. The higher fertilizer used efficiency through better placement of fertilizer and faster drying of the top portion of raised bed is responsible for reduced infestation.

4.3. Input Water Use. The differences in total water use between these two methods were $42 \%$ higher in conventional over bed planting method for the entire cropping period (Table 8). Similarly, Thompson et al. [22] grew rice on both raised beds and flat layout in small plots. They found that irrigation water savings of about $14 \%$ using beds compared with flat layout. Studies in the USA have also shown considerable water saving with furrow irrigated rice on raised bed over conventional flooding method [23]. Likewise, Beecher et al. [24] found that water use in flat and raised bed methods were 18.7 and $15.1 \mathrm{ML} \mathrm{ha}^{-1}$, respectively. They recommended that there is a good scope for saving water while maintaining yield on suitable rice soil through the use of raised beds. In another study, Boulal et al. [25] speculated that compared to conventional method, the introduction of the raised bed planting system resulted in higher soil resistance to the penetration in the upper soil profile. This may protect deep percolation of irrigation water in the field. Regardless of that Fahong et al. [26] suggested that the better performance of raised bed over conventional methods was considered to be due to reduced water logging, improved soil physical properties, reduced lodging, and decreased incidence of disease. However, our speculation is that the advantages come from the fact that irrigation water advances faster on bed planting soil than in a tilled soil and less water percolation loss in bed planting method over conventional method.

\section{Conclusion}

This study concludes that raised beds increased rice yield $16 \%$ than by the conventional tillage on the flat. Raised bed also reduced irrigation water requirement by $42 \%$ and so increased irrigation efficiency. This findings conclude that water and fertilizer use efficiency for grain production and crop productivity were higher in bed planting than conventional method. The potential gains from growing rice production on raised beds are considered to be associated with better agronomic management than conventional method. Also, the crust problem on the soil surface was eliminated and soil physical status was greatly improved in bed planting plot over conventional flat system.

Based on the findings of this single season experiment, high yielding aman rice (depends on both irrigation and rainfall) crops have been successfully grown on raised bed; however, this research needs further validation. In this perspective, further study is under way to investigate yield and growth response of transplanted boro rice (completely 
depends on irrigation) under conventional and bed planting method. Therefore, further research about raised bed over conventional method will be focused on water and fertilizer use efficiency for boro rice (irrigated) production.

\section{Acknowledgments}

The authors are thankful to the farmer who leases his land for this experiment. The author also thanks the pump operator for his kind help to irrigate the land. The authors are deeply indebted to the authorities of Bangladesh Rice research institute (BRRI), Local weather office, Chuadanga and seed processing unit, and Bangladesh Agricultural Development Corporation (BADC), Chuadanaga for their assistance and constructive suggestion.

\section{References}

[1] BBS: Bangladesh Bureau of Statistics, Bangladesh Statistics Bureau, Ministry of Planning Commission, Government of the People's Republic of Bangladesh, 2011.

[2] P. K. Sharma and S. K. De Datta, "Physical properties and process of puddled rice soil," Advances in Soil Science, vol. 5, pp. 139-178, 1986.

[3] W. H. Utomo, B. Prastowo, T. Adisarwanto, E. V. Dacanay, G. S. Kirchhof, and H. B. So, "Soil puddling and rice growth," in Management of Clay Soil for Lowland Rice-Based Cropping Systems, G. S. Kirchhof and H. B. So, Eds., vol. 70 of ACIAR Proceedings, pp. 90-94, Australian Centre for International Agricultural Research, Canberra. Australia.

[4] M. N. F. Elahi, M. I. U. Mollah, S. M. R. Karim, A. Khatun, and N. H. Chaudhury, "New establishment methods of rice and non-rice crops in rice-wheat and rice-rice cropping systems," in Proceedings of the International Workshop on Conservation Agriculture for Fiid Security and Environment Protection in Rice-Wheat Cropping Systems, Lahore, Pakistan, February 2001.

[5] A. K. Borrell, R. M. Kelly, and D. E. Van Cooten, "Improving management of rice in semi-arid eastern Indonesia: responses to irrigation, plant type and nitrogen," Australian Journal of Experimental Agriculture, vol. 38, no. 3, pp. 261-271, 1998.

[6] Y. Singh, E. Humphreys, S. S. Kukal et al., "Crop performance in permanent raised bed rice-wheat cropping system in Punjab, India," Field Crops Research, vol. 110, no. 1, pp. 1-20, 2009.

[7] A. Yadav, R. K. Malik, B. S. Chouhan et al., "Feasibility of raising wheat on furrow irrigated raised beds in South-Western Haryana," in Proceedings of the International Workshop on Herbicide Resistance Management and Zero Tillage in RiceWheat, p. 83, 2002.

[8] M. Zhongming and W. Fahong, "Raised bed- planting system for irrigated spring wheat in Hexi Corridor," in Proceedings of the ACIAR Workshop on Permanent Bed Planting Systems, Griffith, NSW, Australia, March 2005.

[9] C. A. Meisner, H. M. Talukdar, I. Hossain et al., "Introduction and implementing a permanent bed system in the rice-wheat cropping pattern in Bangladesh and Pakistan," in Proceedings of the ACIAR Workshop on Permanent Bed Planting Systems, Griffith, NSW, Australia, March 2005.

[10] B. U. Choudhury, B. A. M. Bouman, and A. K. Singh, "Yield and water productivity of rice-wheat on raised beds at New
Delhi, India," Field Crops Research, vol. 100, no. 2-3, pp. 229239, 2007.

[11] P. R. Hobbs and R. K. Gupta, "Resource-conserving technologies for wheat in the rice-wheat system," in Improving Productivity and Sustainability of Rice-Wheat Systems: Issues and Impact, American society of Agronomy Special Publication 65, pp. 149-217, 2003.

[12] V. Balasubramanian, J. K. Ladha, R. K. Gupta, R. K. Naresh, R. S. Mehla, and Y. Bijay-singh, "Technology option for rice in the rice- wheat systems in Asia," in Improving Productivity and Sustainability of Rice-Wheat Systems: Issues and Impact, American society of Agronomy Special Publication 65, pp. 115-148, 2003.

[13] M. L. Jat and S. K. Sharma, "On-farm studies on FIRB system for improving crop and water productivity and profitability in rice-wheat cropping system," Agenda Notes, 3rd Regional Technical Conrdination Committee Meeting of RWC For the IGP, Technical Conrdination Committee, Dhaka, Bangladesh, Feb 2005.

[14] Y. L. Tang, J. G. Zheng, and G. Huang, "Studies on permanentbed-planting with double zero tillage for rice and wheat in Sichuan basin," Southwest China Journal of Agricultural Sciences, vol. 18, no. 1, pp. 25-28, 2005.

[15] S. E. Ockerby and S. Fukai, "The management of rice grown on raised beds with continuous furrow irrigation," Field Crops Research, vol. 69, no. 3, pp. 215-226, 2001.

[16] E. Humphreys, C. Meisner, R. Gupta et al., "Water saving in rice-wheat systems," Plant Production Science, vol. 8, no. 3, pp. 242-258, 2005.

[17] B. Govaerts, K. D. Sayre, J. M. Ceballos-Ramirez et al., "Conventionally tilled and permanent raised beds with different crop residue management: effects on soil C and N dynamics," Plant and Soil, vol. 280, no. 1-2, pp. 143-155, 2006.

[18] S. Singh, J. K. Ladha, R. K. Gupta, L. Bhushan, and A. N. Rao, "Weed management in aerobic rice systems under varying establishment methods," Crop Protection, vol. 27, no. 3-5, pp. 660-671, 2008.

[19] J. Y. Ram, D. S. Singh, Kler, K. Kumar, I. Humphreys, and J. Timsina, "Performance crops and alternative cropping systems on permanent raised beds in the Indo-Gangetic plains of north-western India," in Proceedings of the ACIAR Wordshop on Permanent Bed Planting Systems, Griffith, NSW, Australia, March 2005.

[20] P. R. Hobbs, "Tillage and crop establishment in South Asian rice-wheat systems: present practices and future options," Journal of Crop Production, vol. 4, no. 1, pp. 1-22, 2001.

[21] M. L. Jat, S. Singh, H. K. Rai, R. S. Chhokar, S. K. Sharma, and R. K. Gupta, "Furrow Irrigated Raised Bed (FIRB) planting technique for diversification of rice-wheat system in indo-gangetic plains," Japan Association For International Collaboration of Agriculture and Forestry, vol. 28, no. 1, pp. 2542, 2005.

[22] J. Thompson, D. Griffin, and S. North, "Improving the water use efficiency of rice," Tech. Rep. 1204, Co-operative Research Centre for Sustainable Rice Production, Yanco, NSW, Australia, 2003.

[23] E. Vories, P. Counce, and T. C. Keisling, "Comparison of flooded and furrow-irrigated rice on clay," Irrigation Science, vol. 21, no. 3, pp. 139-144, 2002.

[24] H. G. Beecher, B. W. Dunn, J. A. Thompson, E. Humphreys, S. K. Mathews, and J. Timsina, "Effect of raised beds, irrigation and nitrogen management on growth, water use and yield of rice in south-eastern Australia," Australian Journal of Experimental Agriculture, vol. 46, no. 10, pp. 1363-1372, 2006. 
[25] H. Boulala, H. Gómez-Macphersona, and F. J. Villalobosa, "Permanent bed planting in irrigated Mediterranean conditions: short-term effects on soil quality, crop yield and water use efficiency," Field Crops Research, vol. 130, pp. 120-127, 2012.

[26] W. Fahong, W. Xuqing, and K. Sayre, "Comparison of conventional, flood irrigated, flat planting with furrow irrigated, raised bed planting for winter wheat in China," Field Crops Research, vol. 87, no. 1, pp. 35-42, 2004. 




Scientifica
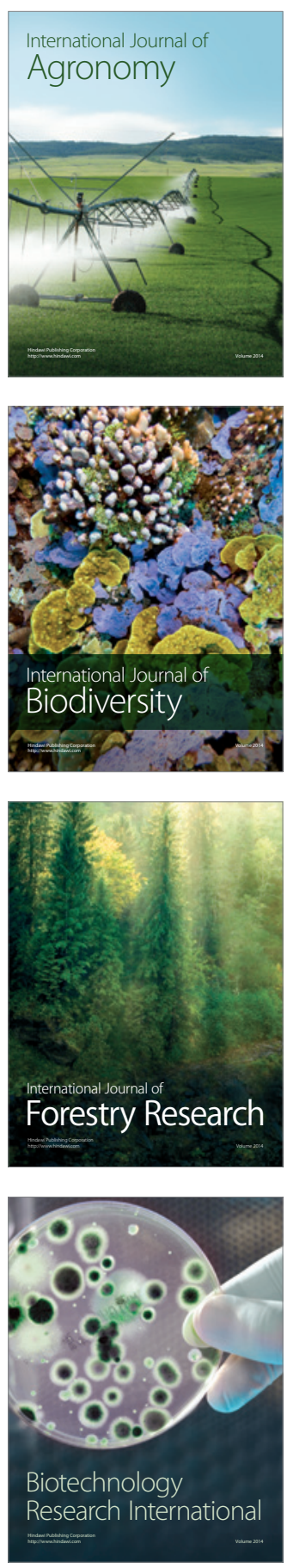
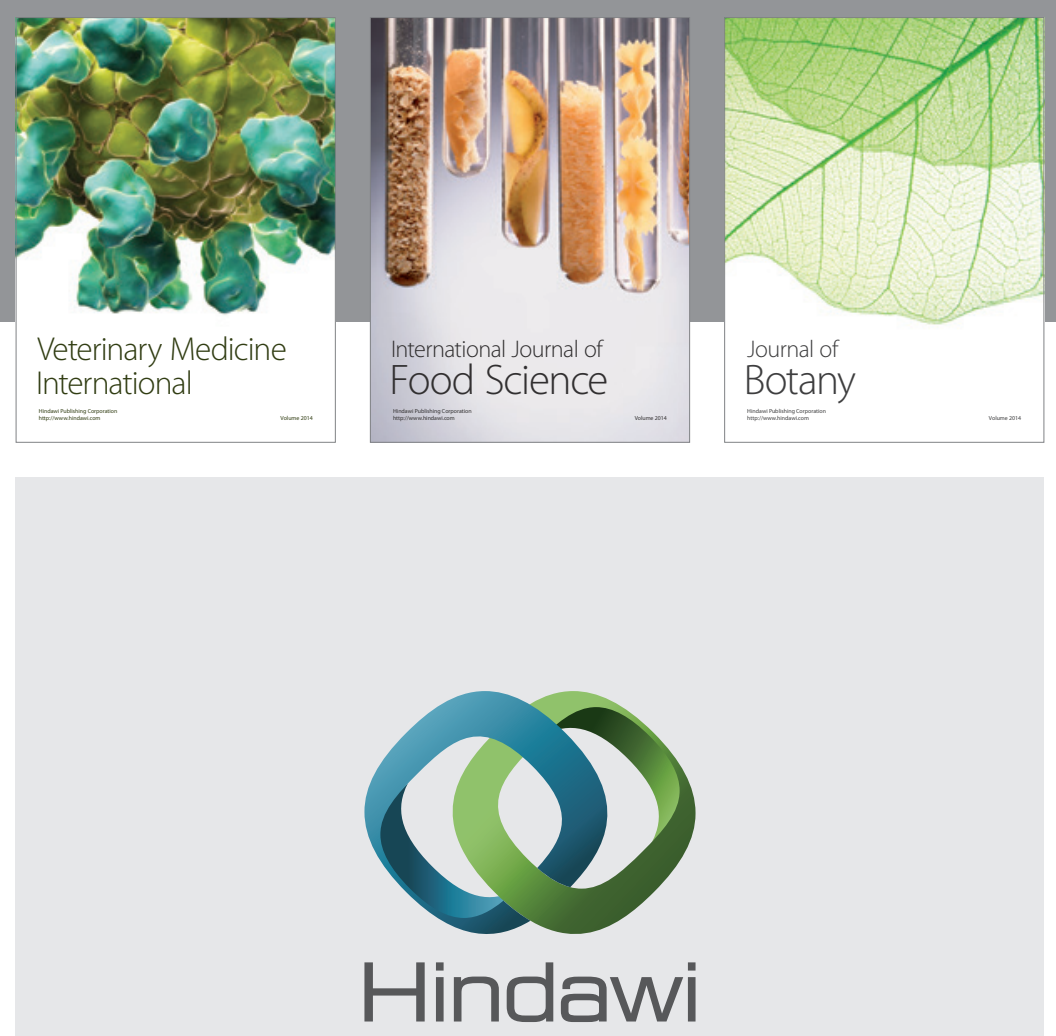

Submit your manuscripts at

http://www.hindawi.com
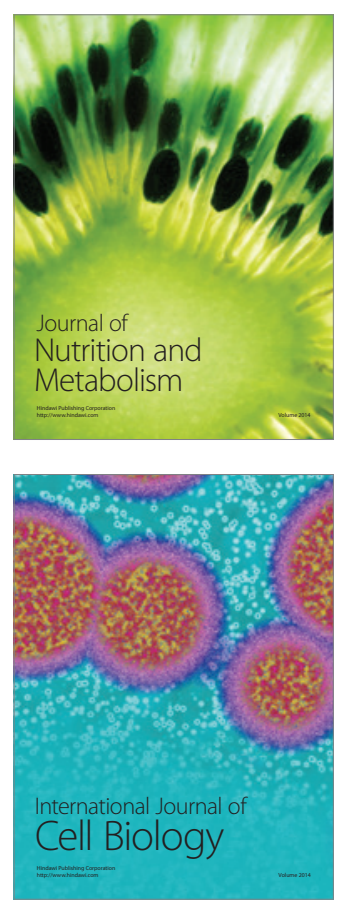
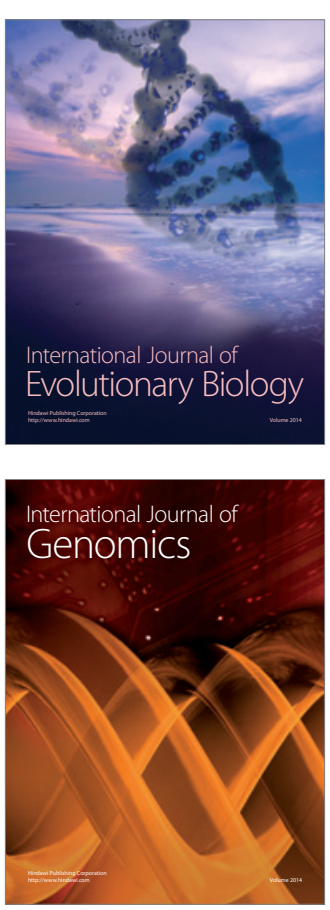
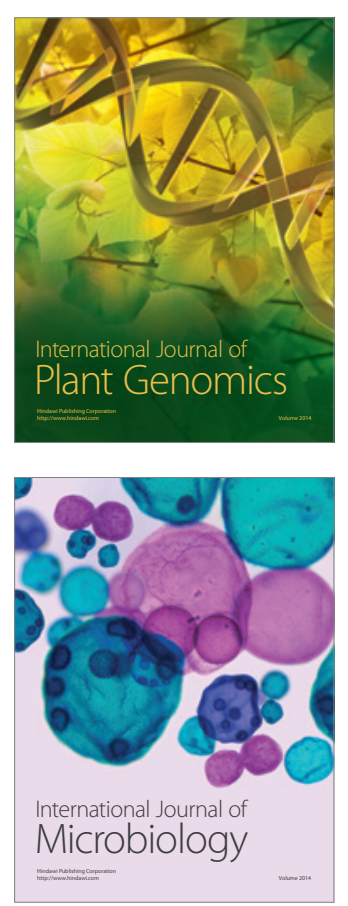

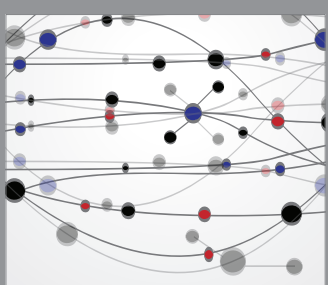

The Scientific World Journal
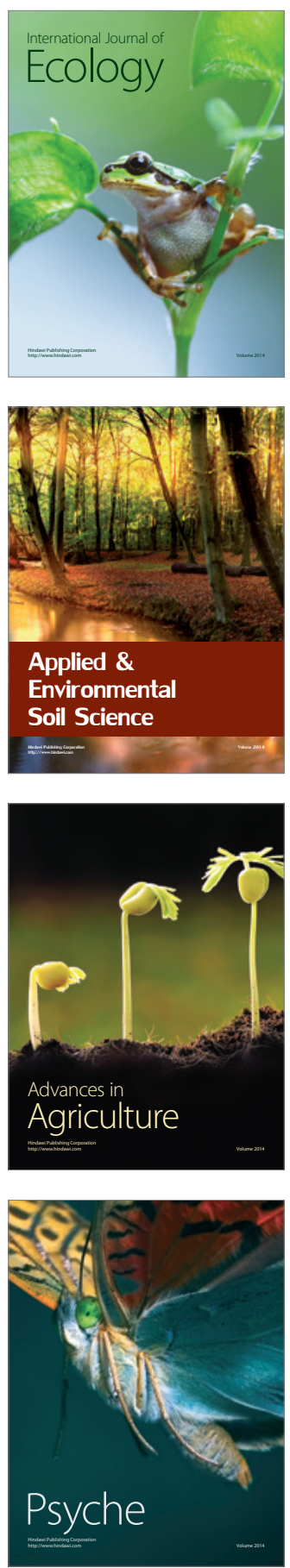